\title{
The complete mitochondrial genome of Pentatoma rufipes (Hemiptera, Pentatomidae) and its phylogenetic implications
}

\author{
Ling Zhao',", Jiufeng Wei ${ }^{1,}$, Wanqing Zhao², \\ Chao Chen', Xiaoyun Gao', Qing Zhao'
}

I College of Plant Protection, Shanxi Agricultural University, Taigu 030801, Shanxi, China 2 Department of Biology, Xinzhou Teachers University, Xinzhou 034000, Shanxi, China

Corresponding author: Qing Zhao (zhaoqing@sxau.edu.cn)

Academic editor: L. Livermore | Received 21 December 2020 | Accepted 24 May 2021 | Published 8 June 2021

http://zoobank.org/B80A1A95-A189-4CC1-9D5F-7F0C80CD9FFO

Citation: Zhao L, Wei J, Zhao W, Chen C, Gao X, Zhao Q (2021) The complete mitochondrial genome of Pentatoma rufipes (Hemiptera, Pentatomidae) and its phylogenetic implications. ZooKeys 1042: 51-72. https://doi.org/10.3897/ zookeys.1042.62302

\begin{abstract}
Pentatoma rufipes (Linnaeus, 1758) is an important agroforestry pest widely distributed in the Palaearctic region. In this study, we sequence and annotate the complete mitochondrial genome of $P$. rufipes and reconstruct the phylogenetic trees for Pentatomoidea using existing data for eight families published in the National Center for Biotechnology Information database. The mitogenome of P. rufipes is 15,887-bp-long, comprising 13 protein-coding genes, 22 transfer RNA genes, two ribosomal RNA genes, and a control region, with an $\mathrm{A}+\mathrm{T}$ content of $77.7 \%$. The genome structure, gene order, nucleotide composition, and codon usage of the mitogenome of $P$. rufipes were consistent with those of typical Hemiptera insects. Among the protein-coding genes of Pentatomoidea, the evolutionary rate of ATP8 was the fastest, and COX1 was found to be the most conservative gene in the superfamily. Substitution saturation assessment indicated that neither transition nor transversion substitutions were saturated in the analyzed datasets. Phylogenetic analysis using the Bayesian inference method showed that $P$. rufipes belonged to Pentatomidae. The node support values based on the dataset concatenated from protein-coding and RNA genes were the highest. Our results enrich the mitochondrial genome database of Pentatomoidea and provide a reference for further studies of phylogenetic systematics.
\end{abstract}

\section{Keywords}

Mitogenome, Pentatomoidea, phylogenetic analysis

\footnotetext{
* These authors contributed equally to this work.
}

Copyright Ling Zhao et al. This is an open access article distributed under the terms of the Creative Commons Attribution License (CC BY 4.0), which permits unrestricted use, distribution, and reproduction in any medium, provided the original author and source are credited. 


\section{Introduction}

The mitochondrion is a semi-autonomous organelle with its own genetic material, known as the mitochondrial genome (mitogenome) (Nass and Nass 1963). The mitogenome is widely used in the fields of molecular evolution, phylogenetic analysis, molecular ecology, biogeography, and population genetics because of its advantages of small size, stable genetic composition, and maternal inheritance (Ballard and Whitlock 2004; Simon and Hadrys 2013; Cameron 2014; Yuan and Guo 2016). Insects, as the most diverse, numerous, and widely distributed animals on Earth, are hotspots in mitogenome research (Boore 1999). To date, mitochondrial genome research has been very extensive, covering all orders of insects (Cameron 2014). Insect mitogenomes are covalently closed, double-stranded, circular DNA molecules (14-20 k bp long), and usually contain a control region and 37 genes: 13 protein-coding genes (PCGs), 22 transfer RNA (tRNA) genes, and two ribosomal RNA (12S rRNA and 16S rRNA) genes (Boore 1999; Cameron and Whiting 2008; Cameron 2014). The structure of mitogenome in most known insects is stable, and the gene arrangement is relatively conservative, which are consistent with the genome composition and arrangement of the most typical insect mitochondrial genome, namely Drosophila yakuba Burla (Clary and Wolstenholme 1985).

Pentatomoidea, one of the most commonly encountered groups in Hemiptera, includes 1,410 genera and 8,042 species which are widely distributed worldwide (Rider et al. 2018). Pentatomoid insects have diverse feeding habits, although the majority are herbivorous. Some cause huge economic losses, such as Dolycoris baccarum (Linnaeus) and Halyomorpha halys Stål. In addition, some pentatomoid insects are predatory, including most of the species of Asopinae; and a few groups are suspected to be fungus feeders, such as members of the Canopidae and Megarididae (Rider et al. 2018; Zhao et al. 2018). Classification of the superfamily Pentatomoidea has long been contentious; and different scholars have distinct opinions. For example, Schaefer (1993) divided Pentatomoidea into 16 families, whereas Henry (1997) recognized 17 families, placing Eumenotidae and Thyreocoridae at the family level. Grazia et al. (2008) supported the monophyly of Pentatomoidea and most of the included families, which was based on morphological characters and molecular markers (16S rRNA, 18S rRNA, $28 \mathrm{~S}$ rRNA and COI); Wu et al. (2016) reconstructed the phylogenetic relationships of 16 families within Pentatomoidea using $18 \mathrm{~S}$ and $28 \mathrm{~S}$ rDNAs sequences and showed that Cydnidae and Tessaratomidae might be polyphyletic; Lis et al. (2017) combined $28 \mathrm{~S}+18 \mathrm{~S}$ rDNA sequence, questioned the monophyleticity of the "cydnoid" complex of pentatomoid families (Cydnidae, Parastrachiidae, Thaumastellidae, and Thyreocoridae), and demonstrated the polyphylicity of Cydnidae. Recently, many taxonomists reorganized the families, genera, and species of Pentatomoidea, and divided Pentatomoidea into 18 families (Rider et al. 2018). With the development of next-generation sequencing (NGS), an increasing number of pentatomoid mitogenome sequences have been obtained, which provide the possibility of resolving the phylogenetic relationships 
among the superfamily at the genetic level (Yuan et al. 2015b; Bai et al. 2018; Zhao et al. 2018). Furthermore, Wu et al. (2017) confirmed the monophyly of Scutelleridae (based on $18 \mathrm{~S}+28 \mathrm{~S}$ rDNAs + 13PCGs), and Liu et al. (2019) reconstructed the phylogeny of Pentatomomorpha and Pentatomoidea based on PCGRNA and PCG12RNA. However, despite the abundance of species in the superfamily, only 97 species have complete or nearly complete mitogenomes published in the National Center for Biotechnology Information (NCBI; https://www.ncbi.nlm.nih.gov/2020.07); these represent only eight families. Moreover, there has been no discussion about the phylogenetic position of Pentatoma species, except for the description of Pentatoma semiannulata (Motschulsky) mitogenome by Wang et al. (2021). Therefore, it is necessary to determine more mitogenome sequences of Pentatoma species to better understand its phylogenetic relationships.

Pentatoma rufipes (Linnaeus, 1758) (Hemiptera, Heteroptera, Pentatomidae) is a medium-sized to large, dark brown insect with reddish-orange spots and bright orange legs (Hsiao 1977; Bantock and Botting 2013). These insects are widely distributed in the Palearctic region (Ling and Zheng 1987; Fan and Liu 2012). They can damage oak, poplar, elm, hawthorn, apricot, pear, and other trees, and they constitute an important agricultural and forestry pest (Hsiao et al. 1977; Powell 2020). There are also records of P. rufipes preying on Zygaena filipendulae L.(Lepidoptera, Zygaenidae) (Hamilton and Heath 1976). Previous studies on P. rufipes mostly focused on its physiological and morphological characteristics (Ling and Zheng 1987; Neupert et al. 2009), with limited molecular data on the mitochondrial COI and COII genes (Bu et al. 2005; Liang 2009), along with some studies identifying biological characteristics and potential control strategies (Peusens and Beliën 2012; Powell 2020).

In this study, we sequenced and annotated the mitogenome of P. rufipes and analyzed its mitogenome in detail, including the genome structure, nucleotide composition, and codon usage, and constructed RNA secondary structures. In addition, we combined the complete mitogenome of P. rufipes with the existing data for the eight families of Pentatomoidea to explore the phylogenetic position of P. rufipes.

\section{Materials and methods}

\section{Sample collection}

Adult Pentatoma rufipes specimens were collected in Baiji Hill (Tonghua City, Jilin Province, China; $\left.41^{\circ} 58.14^{\prime} \mathrm{N}, 1^{\circ} 6^{\circ} 06.58^{\prime} \mathrm{E}\right)$ on 24 July 2015 . All samples were immediately placed in absolute ethanol and stored in a freezer at $-20^{\circ} \mathrm{C}$ until DNA extraction. Specimen identification was performed by Qing Zhao. The voucher specimen is maintained at the Institute of Entomology of Shanxi Agricultural University (voucher number: SXAU 007; Taigu, China). The complete mitogenome of $P$. rufipes has been submitted to GenBank (accession number: MT861131). 


\section{DNA extraction and sequencing}

Whole-genome DNA was extracted from the thoracic muscle of adult samples using the Genomic DNA Extraction Kit (Sangon Biotech, Shanghai, China). The mitogenomes were sequenced using the whole-genome shotgun method on the Illumina Miseq platform (Personalbio, Shanghai, China), with 400-bp inserts and paired-end model. A5-miseq v. 20150522 (Coil et al. 2015) and SPAdes v. 3.9 (Bankevich et al. 2012) were used to assemble the data.

\section{Genome annotation and sequence analysis}

After assembly, the complete mitogenome was manually annotated using Geneious v. 8.1.4 software (Kearse et al. 2012). A reference sequence of Eurydema gebleri Kolenati for annotation was obtained from the basic local alignment search tool (BLAST) in the NCBI database. The boundaries of the PCGs were determined using Open Reading Frame Finder (http://www.ncbi.nlm.nih.gov/gorf/gorf.html) on the NCBI website. MEGA v. 7.0 (Kumar et al. 2016) was used to translate the proteins to verify the start codons, stop codons, and amino acid sequences and to ensure the accuracy of the sequences. We annotated tRNA sequences using tRNAscan-SE (http://lowelab. ucsc.edu/tRNAscan-SE/) (Lowe and Eddy 1997) and MITOS (http://mitos.bioinf. uni-leipzig.de/index.py/) (Bernt et al. 2013) with the invertebrate mitochondrial code. The boundaries of rRNA genes were completed according to the positions of adjacent genes and published rRNA gene sequences from Pentatomidae insects in GenBank (Boore 2006). The codon usage, base composition, and amino acid composition of the mitogenome were analyzed using MEGA v. 7.0. The skew of the nucleotide composition was calculated with the formulas: AT-skew $=(\mathrm{A}-\mathrm{T}) /(\mathrm{A}+\mathrm{T})$ and GC-skew $=$ $(\mathrm{G}-\mathrm{C}) /(\mathrm{G}+\mathrm{C})$ (Perna and Kocher 1995).

\section{Phylogenetic analyses}

In this study, we selected the mitogenomes of $P$. rufipes, representative species from eight other Pentatomoidea families, and two Coreoidea species (outgroup) to analyze the phylogenetic position of $P$. rufipes and the phylogenetic relationships within Pentatomoidea. All species included in this analysis are listed in Table 1. The nucleic acid sequences of the 13 PCGs were extracted using Geneious v. 8.1.4. All PCGs were translated into their amino acid sequences and aligned using MUSCLE with default parameters in MEGA v. 7.0 (Edgar 2004). The tRNA and rRNA genes were also aligned using the MUSCLE algorithm in MEGA v. 7.0. The resulting alignments were concatenated into a combined matrix.

To determine if the sequences contained phylogenetic information, we tested nucleotide substitution saturation, and plotted transition and transversion substitutions against the TN93 distance for all datasets before reconstructing the phylogenetic trees using DAMBE v. 4.5.32 (Xia and Xie 2001; Xia and Lemey 2009). The optimal sub- 
Table I. List of species used to construct the phylogenetic tree.

\begin{tabular}{|c|c|c|c|}
\hline Classificationstatus & Family & Species & Accession number \\
\hline \multicolumn{4}{|l|}{ Outgroup } \\
\hline \multirow[t]{2}{*}{ Coreoidea } & Coreidae & Hydaropsis longirostris & EU427337 \\
\hline & & Anoplocnemis curvipes & NC_035509 \\
\hline \multicolumn{4}{|l|}{ Ingroup } \\
\hline \multirow[t]{23}{*}{ Pentatomoidea } & Acanthosomatidae & Acanthosoma labiduroides & JQ743670 \\
\hline & & Sastragala edessoides & JQ743676 \\
\hline & & Anaxandra taurina & NC_042801 \\
\hline & Cydnidae & Macroscytus gibbulus & NC_012457 \\
\hline & & Adrisa magna & NC_042429 \\
\hline & & Scoparipes salvazai & NC_042800 \\
\hline & Dinidoridae & Cyclopelta parva & KY069962 \\
\hline & & Megymenum gracilicorne & NC_042810 \\
\hline & Pentatomidae & Halyomorpha halys & NC_013272 \\
\hline & & Eurydema gebleri & NC_027489 \\
\hline & & Graphosoma rubrolineatum & NC_033875 \\
\hline & & Gonopsis affinis & NC_036745 \\
\hline & & Dinorhynchus dybowskyi & NC_037724 \\
\hline & & Plautia fimbriata & NC_042813 \\
\hline & & Pentatoma rufipes & MT861131 \\
\hline & Plataspidae & Coptosoma bifaria & EU427334 \\
\hline & & Megacopta cribraria & NC_015342 \\
\hline & Scutelleridae & Cantao ocellatus & NC_042803 \\
\hline & & Eurygaster testudinaria & NC_042808 \\
\hline & Tessaratomidae & Dalcantha dilatata & JQ910981 \\
\hline & & Eusthenes cupreus & NC_022449 \\
\hline & & Tessaratoma papillosa & NC_037742 \\
\hline & Urostylididae & Urostylis flavoannulata & NC_037747 \\
\hline
\end{tabular}

stitution models for each dataset were calculated using PartitionFinder v. 1.1.1 (Lanfear et al. 2012). Phylogenetic analyses were conducted using the Bayesian inference method, in MrBayes v. 3.2.5 (Ronquist et al. 2012) under the $G T R+G+I$ substitution model with four independent Markov chains run for 10,000,000 generations and stopped when the average standard deviation value was below 0.01 . The first $25 \%$ of trees were discarded as burn-ins, and the remaining trees were used to construct a $50 \%$ majority-rule consensus tree (Zhao et al. 2018). The phylogenetic trees were constructed using three types of datasets: (1) all codon positions of the 13 PCGs; (2) the 13 PCGs, excluding the third codon position (PCG12); and (3) the PCGs, 22 tRNA genes, and two rRNA genes (PCGRNA).

\section{Results}

\section{Genomic features}

The mitochondrial genome of Pentatoma rufipes is 15,887-bp-long and contains a control region and 37 genes comprising 13 PCGs, 22 tRNA genes and two rRNA genes (Fig. 1; Table 2). Among these genes, 14 genes are located on the minority strand 


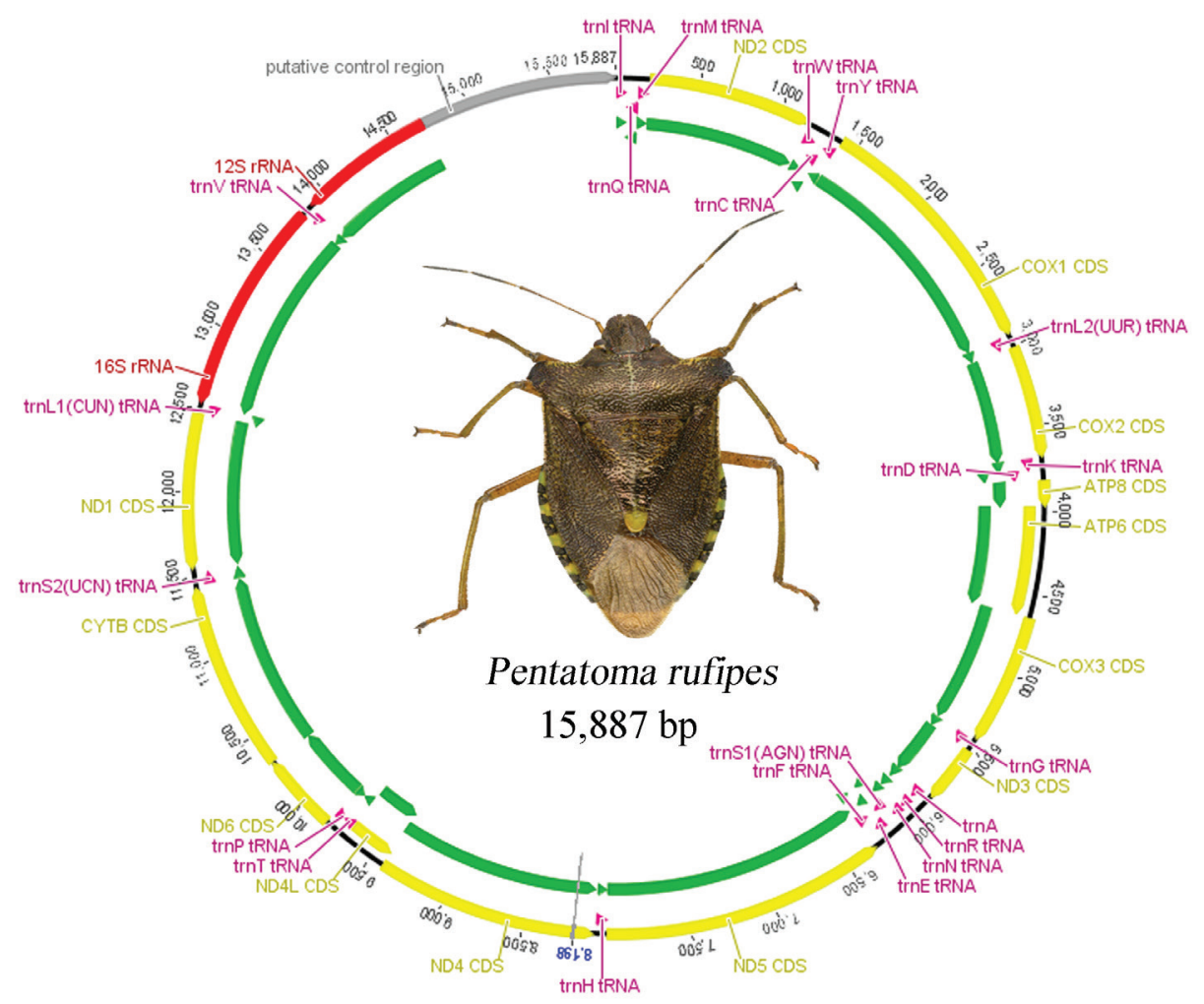

Figure I. Mitochondrial genome map of Pentatoma rufipes. Arrows indicate the orientation of gene transcription. Protein coding and ribosomal genes are shown with standard abbreviations.

(N-strand), including four PCGs (ND5, ND4, ND4L, and ND1), eight tRNA genes (trnQ, $\operatorname{trn} C, \operatorname{trn} Y, \operatorname{trnF}, \operatorname{trn} \mathrm{H}, \operatorname{trn} \mathrm{P}, \operatorname{trnL} 1(\mathrm{CUN})$, and $\operatorname{trn} \mathrm{V})$, and two rRNA genes (12S rRNA and 16S rRNA genes), whereas the remaining 23 genes are encoded on the majority strand (J-strand). The mitogenome is compact, with a total of nine gene overlaps, ranging in length from 1 to $8 \mathrm{bp}$; the longest overlap is between trnW and trnC. Furthermore, there were 16 gene spacers from $1 \mathrm{bp}$ to $23 \mathrm{bp}$, comprising $116 \mathrm{bp}$ in total; the longest spacer region falls between $\operatorname{trnS} 2$ and ND1.

\section{Nucleotide composition and codon usage}

The base content and skewness of the genes in the P. rufipes mitogenome is shown in Table 3. The base composition of the entire sequence is in the order of $\mathrm{A}(42.0 \%)>\mathrm{T}$ ( $35.7 \%)>\mathrm{C}(12.4 \%)>\mathrm{G}(9.9 \%)$, with a bias toward $\mathrm{A}+\mathrm{T}$. This bias was observed in all genetic elements, with an $\mathrm{A}+\mathrm{T}$ content of $77.1 \%$ in PCGs, $77.7 \%$ in tRNAs, $79.8 \%$ in $\mathrm{rRNAs}$, and $78.7 \%$ in the control region. The complete genome also shows a clear AC-skew (AT-skew $=0.08, \mathrm{GC}$-skew $=-0.11)$, indicating a greater abundance of A than $\mathrm{T}$ and of $\mathrm{C}$ than $\mathrm{G}$. 
Table 2. Organization of the mitochondrial genome of Pentatoma rufipes.

\begin{tabular}{|c|c|c|c|c|c|c|c|}
\hline Gene & Strand & Position & Anticodon & Size(bp) & Start codon & Stop codon & Intergenetic nucleotides* \\
\hline $\operatorname{trnI}$ & $\mathrm{J}$ & $1-67$ & GAT & 67 & & & \\
\hline $\operatorname{trn} Q$ & $\mathrm{~N}$ & $65-134$ & TTG & 70 & & & -3 \\
\hline $\operatorname{trnM}$ & $\mathrm{J}$ & $137-205$ & CAT & 69 & & & 2 \\
\hline ND2 & $\mathrm{J}$ & $206-1189$ & & 984 & ATT & TAA & 0 \\
\hline $\operatorname{trn} W$ & $\mathrm{~J}$ & $1198-1265$ & TCA & 68 & & & 8 \\
\hline $\operatorname{trnC}$ & $\mathrm{N}$ & $1258-1321$ & GCA & 64 & & & -8 \\
\hline $\operatorname{trn} Y$ & $\mathrm{~N}$ & $1331-1397$ & GTA & 67 & & & 9 \\
\hline COX1 & $\mathrm{J}$ & $1407-2943$ & & 1537 & TTG & $\mathrm{T}$ & 9 \\
\hline $\operatorname{trnL} 2^{U U R}$ & $\mathrm{~J}$ & $2944-3008$ & TAA & 65 & & & 0 \\
\hline $\operatorname{COX} 2$ & $\mathrm{~J}$ & $3009-3687$ & & 679 & ATA & $\mathrm{T}$ & 0 \\
\hline $\operatorname{trn} K$ & $\mathrm{~J}$ & $3688-3761$ & CTT & 74 & & & 0 \\
\hline $\operatorname{trnD}$ & $\mathrm{J}$ & $3761-3822$ & GTC & 62 & & & -1 \\
\hline ATP8 & $\mathrm{J}$ & $3823-3981$ & & 159 & TTG & TAA & 0 \\
\hline ATP6 & $\mathrm{J}$ & $3975-4649$ & & 675 & ATG & TAA & -7 \\
\hline $\mathrm{COX} 3$ & $\mathrm{~J}$ & $4652-5440$ & & 789 & ATG & TAA & 2 \\
\hline $\operatorname{trnG}$ & $\mathrm{J}$ & $5446-5510$ & TCC & 65 & & & 5 \\
\hline ND3 & $\mathrm{J}$ & $5511-5864$ & & 354 & ATC & TAA & 0 \\
\hline $\operatorname{trn} A$ & $\mathrm{~J}$ & $5873-5943$ & TGC & 71 & & & 8 \\
\hline $\operatorname{trnR}$ & $\mathrm{J}$ & 5960-6024 & TCG & 65 & & & 16 \\
\hline $\operatorname{trn} N$ & $\mathrm{~J}$ & $6033-6101$ & GTT & 69 & & & 8 \\
\hline $\operatorname{trnS} 1^{A G N}$ & $\mathrm{~J}$ & $6101-6170$ & ACT & 70 & & & -1 \\
\hline $\operatorname{trn} E$ & $\mathrm{~J}$ & $6171-6238$ & TTC & 68 & & & 0 \\
\hline $\operatorname{trnF}$ & $\mathrm{N}$ & $6237-6301$ & GAA & 65 & & & -2 \\
\hline ND5 & $\mathrm{N}$ & $6301-8007$ & & 1707 & ATT & TAA & -1 \\
\hline $\operatorname{trnH}$ & $\mathrm{N}$ & $8009-8076$ & GTG & 68 & & & 1 \\
\hline ND4 & $\mathrm{N}$ & $8079-9410$ & & 1332 & ATG & TAA & 2 \\
\hline ND4L & $\mathrm{N}$ & $9404-9691$ & & 288 & ATT & TAA & -7 \\
\hline $\operatorname{trn} \mathrm{T}$ & $\mathrm{J}$ & $9694-9758$ & TGT & 65 & & & 2 \\
\hline $\operatorname{trn} \mathrm{P}$ & $\mathrm{N}$ & $9759-9820$ & TGG & 62 & & & 0 \\
\hline ND6 & $\mathrm{J}$ & 9823-10299 & & 477 & ATG & TAA & 2 \\
\hline CYTB & $\mathrm{J}$ & $10304-11440$ & & 1137 & ATG & TAA & 4 \\
\hline $\operatorname{trnS} 2^{U C N}$ & $\mathrm{~J}$ & $11456-11524$ & TGA & 69 & & & 15 \\
\hline ND1 & $\mathrm{N}$ & $11548-12477$ & & 930 & ATA & TAA & 23 \\
\hline $\operatorname{trnL} 1^{C U N}$ & $\mathrm{~N}$ & $12472-12539$ & TAG & 68 & & & -6 \\
\hline $16 \mathrm{~S}$ rRNA & $\mathrm{N}$ & $12540-13816$ & & 1277 & & & 0 \\
\hline $\operatorname{trnV}$ & $\mathrm{N}$ & $13817-13886$ & TAC & 70 & & & 0 \\
\hline $12 \mathrm{~S}$ rRNA & $\mathrm{N}$ & $13887-14707$ & & 821 & & & 0 \\
\hline CR & & $14708-15887$ & & 1180 & & & 0 \\
\hline
\end{tabular}

"Numbers correspond to nucleotides separating a gene from an upstream one; negative numbers indicate that adjacent cent genes overlap.

The preference for nucleotide composition is also reflected in codon use. The relative synonymous codon usage values for the $P$. rufipes mitogenome are summarized in Figure 2 and Table 4. Figure 3 shows the amino acid composition of the P. rufipes mitogenome. The most common amino acids are Phe, Leu, Ile, and Met, and their most abundant codons (UUU for Phe, UUA for Leu2, AUU for Ile, and AUA for Met) are all composed of A and/or T. For each amino acid, the most commonly used coded codons are NNA and NNU, reflecting the skew of the nucleotide composition toward AT. In addition, the most frequently used codons do not strictly correspond to the tRNA anticodons for most amino acids. 
Table 3. Nucleotide composition and skewness of the Pentatoma rufipes mitochondrial genome.

\begin{tabular}{lcccccccc}
\hline \multicolumn{1}{c}{ Feature } & Length(bp) & $\mathbf{A} \%$ & $\mathbf{C} \%$ & $\mathbf{G} \%$ & $\mathbf{T} \%$ & A+T\% & AT-skew & GC-skew \\
\hline Whole genome & 15737 & 42.0 & 12.4 & 9.9 & 35.7 & 77.7 & 0.08 & -0.11 \\
PCGs & 11046 & 34.2 & 11.1 & 11.8 & 42.9 & 77.1 & -0.11 & 0.03 \\
PCG-J & 6800 & 37.2 & 12.6 & 11.7 & 38.5 & 75.7 & -0.02 & -0.04 \\
PCG-N & 4246 & 29.4 & 8.8 & 11.9 & 49.9 & 79.3 & -0.26 & 0.15 \\
tRNA genes & 1460 & 39.7 & 10.0 & 12.3 & 38.0 & 77.7 & 0.02 & 0.10 \\
tRNA genes-J & 936 & 40.6 & 11.0 & 11.1 & 37.3 & 77.9 & 0.04 & 0.01 \\
tRNA genes-N & 524 & 38.0 & 8.2 & 14.4 & 39.3 & 77.3 & -0.02 & 0.27 \\
rRNA genes & 2053 & 35.6 & 7.6 & 12.6 & 44.2 & 79.8 & -0.11 & 0.25 \\
Control region & 1142 & 38.3 & 13.6 & 7.6 & 40.4 & 78.7 & -0.03 & -0.28 \\
\hline
\end{tabular}

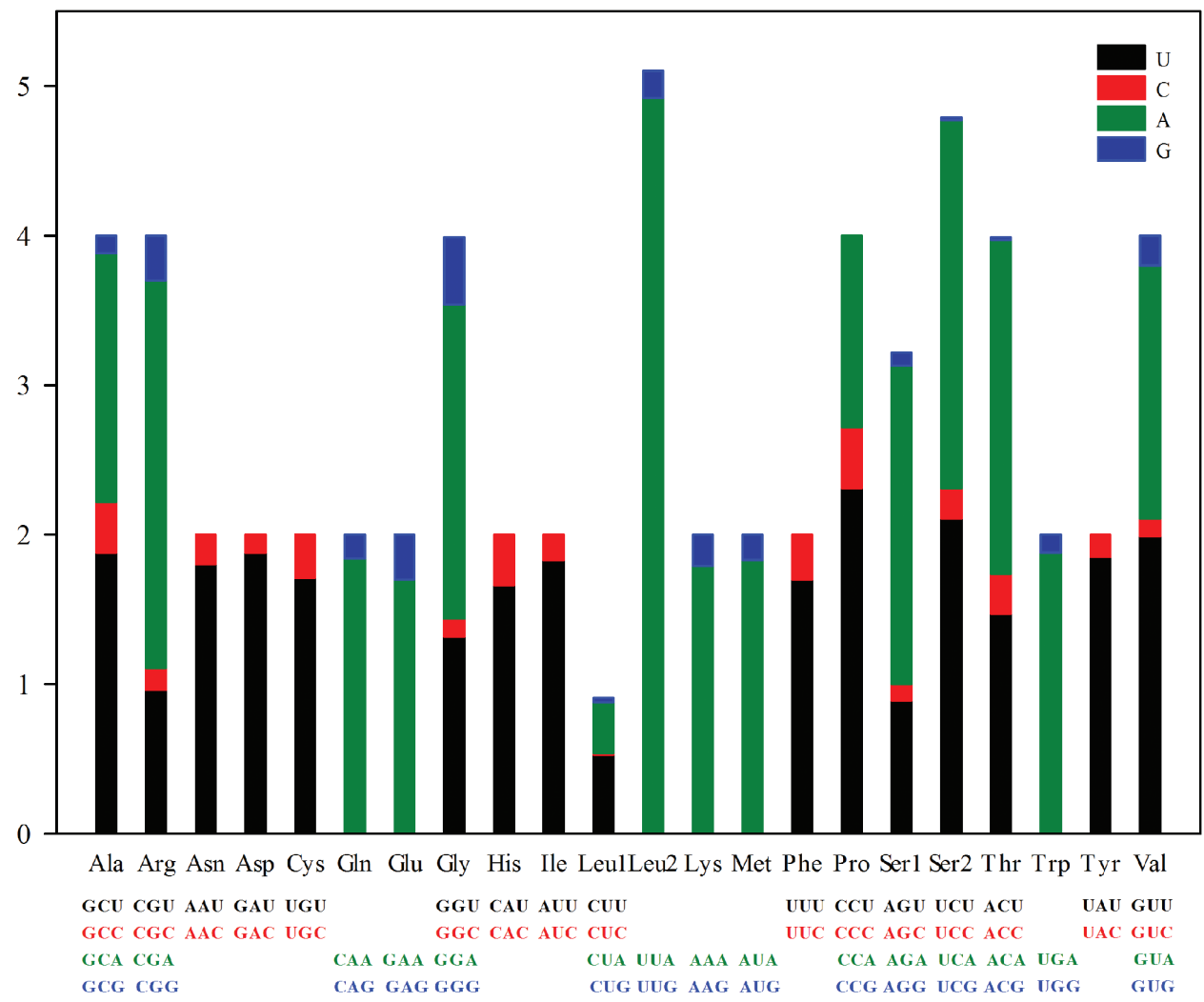

Figure 2. The relative synonymous codon usage (RSCU) in the mitogenome of Pentatoma rufipes.

\section{PCG regions}

Most P. rufipes PCGs share the ATN start codon (five with ATG, three with ATT, two with ATA, and one with ATC), except for COX1 and ATP8, which start with TTG. COX1 and COX2 sequences terminate with a single $T$, and the stop codon for the remaining genes is TAA. The AT content $(77.1 \%)$ of the 13 PCGs exceeded the GC content $(22.9 \%)$, and the AT bias is moderately negative (absolute value: $0.1-0.2$ ). 
Table 4. Codon number and RSCU in the Pentatoma rufipes mitochondrial PCGs.

\begin{tabular}{|c|c|c|c|c|c|c|c|}
\hline Amino acid & Codon & $\mathbf{N}$ & RSCU & $\mathrm{N}_{+}$ & RSCU+ & $\mathrm{N}-$ & RSCU_- \\
\hline \multirow[t]{2}{*}{ Phe } & UUU & 260 & 1.7 & 118 & 1.49 & 142 & 1.92 \\
\hline & $\underline{\text { UUC }}$ & 46 & 0.3 & 40 & 0.51 & 6 & 0.08 \\
\hline \multirow[t]{2}{*}{ Leu2 } & $\underline{\mathrm{UUA}}$ & 440 & 4.92 & 238 & 4.89 & 202 & 4.95 \\
\hline & UUG & 16 & 0.18 & 6 & 0.12 & 10 & 0.24 \\
\hline \multirow[t]{4}{*}{ Leu1 } & CUU & 47 & 0.53 & 19 & 0.39 & 28 & 0.69 \\
\hline & CUC & 1 & 0.01 & 1 & 0.02 & 0 & 0 \\
\hline & $\underline{\mathrm{CUA}}$ & 30 & 0.34 & 26 & 0.53 & 4 & 0.1 \\
\hline & CUG & 3 & 0.03 & 2 & 0.04 & 1 & 0.02 \\
\hline \multirow[t]{2}{*}{ Ile } & AUU & 382 & 1.83 & 255 & 1.8 & 127 & 1.91 \\
\hline & $\underline{\text { AUC }}$ & 35 & 0.17 & 29 & 0.2 & 6 & 0.09 \\
\hline \multirow[t]{2}{*}{ Met } & AUA & 274 & 1.83 & 179 & 1.86 & 95 & 1.78 \\
\hline & $\underline{\mathrm{AUG}}$ & 25 & 0.17 & 13 & 0.14 & 12 & 0.22 \\
\hline \multirow[t]{4}{*}{ Val } & GUU & 80 & 1.99 & 33 & 1.43 & 47 & 2.72 \\
\hline & GUC & 5 & 0.12 & 1 & 0.04 & 4 & 0.23 \\
\hline & $\underline{\text { GUA }}$ & 68 & 1.69 & 51 & 2.22 & 17 & 0.99 \\
\hline & GUG & 8 & 0.2 & 7 & 0.3 & 1 & 0.06 \\
\hline \multirow[t]{4}{*}{ Ser2 } & UCU & 95 & 2.11 & 31 & 1.24 & 64 & 3.18 \\
\hline & UCC & 9 & 0.2 & 6 & 0.24 & 3 & 0.15 \\
\hline & $\underline{\mathrm{UCA}}$ & 111 & 2.46 & 76 & 3.04 & 35 & 1.74 \\
\hline & UCG & 1 & 0.02 & 0 & 0 & 1 & 0.05 \\
\hline \multirow[t]{4}{*}{ Pro } & $\mathrm{CCU}$ & 74 & 2.31 & 48 & 2.04 & 26 & 3.06 \\
\hline & CCC & 13 & 0.41 & 9 & 0.38 & 4 & 0.47 \\
\hline & $\underline{\mathrm{CCA}}$ & 41 & 1.28 & 37 & 1.57 & 4 & 0.47 \\
\hline & CCG & 0 & 0 & 0 & 0 & 0 & 0 \\
\hline \multirow[t]{4}{*}{ Thr } & $\mathrm{ACU}$ & 60 & 1.47 & 42 & 1.33 & 18 & 1.95 \\
\hline & ACC & 11 & 0.27 & 5 & 0.16 & 6 & 0.65 \\
\hline & $\underline{\mathrm{ACA}}$ & 91 & 2.23 & 78 & 2.48 & 13 & 1.41 \\
\hline & ACG & 1 & 0.02 & 1 & 0.03 & 0 & 0 \\
\hline \multirow[t]{4}{*}{$\mathrm{Ala}$} & GCU & 61 & 1.88 & 42 & 1.77 & 19 & 2.17 \\
\hline & GCC & 11 & 0.34 & 9 & 0.38 & 2 & 0.23 \\
\hline & GCA & 54 & 1.66 & 44 & 1.85 & 10 & 1.14 \\
\hline & GCG & 4 & 0.12 & 0 & 0 & 4 & 0.46 \\
\hline \multirow[t]{2}{*}{ Tyr } & UAU & 170 & 1.85 & 67 & 1.7 & 103 & 1.96 \\
\hline & $\underline{\mathrm{UAC}}$ & 14 & 0.15 & 12 & 0.3 & 2 & 0.04 \\
\hline \multirow[t]{2}{*}{ His } & $\mathrm{CAU}$ & 59 & 1.66 & 45 & 1.58 & 14 & 2 \\
\hline & $\underline{\mathrm{CAC}}$ & 12 & 0.34 & 12 & 0.42 & 0 & 0 \\
\hline \multirow[t]{2}{*}{ Gln } & CAA & 47 & 1.84 & 35 & 2 & 12 & 1.5 \\
\hline & CAG & 4 & 0.16 & 0 & 0 & 4 & 0.5 \\
\hline \multirow[t]{2}{*}{ Asn } & AAU & 179 & 1.8 & 114 & 1.74 & 65 & 1.91 \\
\hline & $\underline{\mathrm{AAC}}$ & 20 & 0.2 & 17 & 0.26 & 3 & 0.09 \\
\hline \multirow[t]{2}{*}{ Lys } & AAA & 102 & 1.79 & 73 & 1.9 & 29 & 1.57 \\
\hline & $\underline{\mathrm{AAG}}$ & 12 & 0.21 & 4 & 0.19 & 8 & 0.43 \\
\hline \multirow[t]{2}{*}{ Asp } & GAU & 63 & 1.88 & 38 & 1.81 & 25 & 2 \\
\hline & $\underline{\text { GAC }}$ & 4 & 0.12 & 4 & 0.19 & 0 & 0 \\
\hline \multirow[t]{2}{*}{ Glu } & GAA & 73 & 1.7 & 56 & 1.9 & 17 & 1.26 \\
\hline & GAG & 13 & 0.3 & 3 & 0.1 & 10 & 0.74 \\
\hline \multirow[t]{2}{*}{ Cys } & UGU & 42 & 1.71 & 12 & 1.6 & 30 & 1.76 \\
\hline & $\underline{\mathrm{UGC}}$ & 7 & 0.29 & 3 & 0.4 & 4 & 0.24 \\
\hline \multirow[t]{2}{*}{ Trp } & $\underline{\mathrm{UGA}}$ & 91 & 1.88 & 68 & 1.97 & 23 & 1.64 \\
\hline & UGG & 6 & 0.12 & 1 & 0.03 & 5 & 0.36 \\
\hline
\end{tabular}




\begin{tabular}{lccccccc}
\hline Amino acid & Codon & N & RSCU & N+ & RSCU+ & N- & RSCU- \\
\hline Arg & CGU & 13 & 0.96 & 2 & 0.23 & 11 & 2.32 \\
& CGC & 2 & 0.15 & 1 & 0.11 & 1 & 0.21 \\
& CGA & 35 & 2.59 & 30 & 3.43 & 5 & 1.05 \\
\multirow{5}{*}{ Ser1 } & CGG & 4 & 0.3 & 2 & 0.23 & 2 & 0.42 \\
& AGU & 40 & 0.89 & 14 & 0.56 & 26 & 1.29 \\
& AGC & 5 & 0.11 & 3 & 0.12 & 2 & 0.1 \\
Gly & AGA & 96 & 2.13 & 69 & 2.76 & 27 & 1.34 \\
& AGG & 4 & 0.09 & 1 & 0.04 & 3 & 0.15 \\
& GGU & 64 & 1.32 & 28 & 0.9 & 36 & 2.06 \\
& GGC & 6 & 0.12 & 2 & 0.06 & 4 & 0.23 \\
& GGA & 102 & 2.1 & 82 & 2.65 & 20 & 1.14 \\
\hline
\end{tabular}

$\mathrm{N}, \mathrm{N}_{+}$, and $\mathrm{N}-$ are respectively the number of codons used in the total protein codon gene, the majority strand protein codon gene (J-strand), and the minority strand protein codon gene ( $\mathrm{N}$-strand). Values in bold type stand for most commonly used codon for the amino acid. Underlined codons stand for the cognate codon of tRNA for each amino acid.

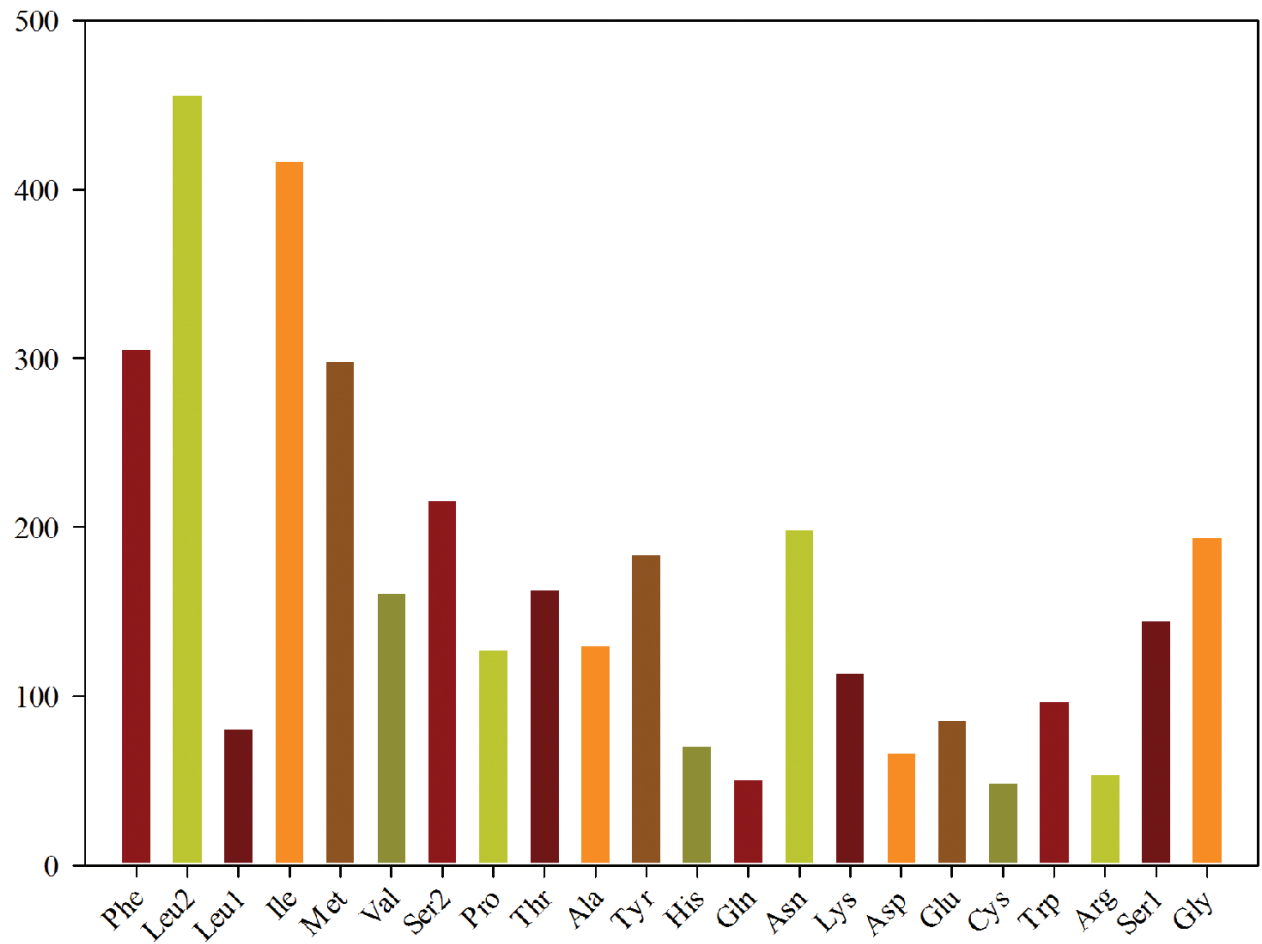

Figure 3. Amino acid composition in the Pentatoma rufipes mitogenome. Codon families are provided on the $\mathrm{x}$-axis. Numbers of codons of each amino acid are provided on the $\mathrm{y}$-axis.

In addition, we calculated the synonymous substitutions (Ks), non-synonymous substitutions (Ka), and the Ka/Ks ratios of the 13 PCGs from Pentatomoid insects. We also compared the evolutionary rates of the 13 PCGs (Fig. 4). The evolutionary rate of ATP8 was the fastest, followed by that of ND6, and the COX1 gene was the most 


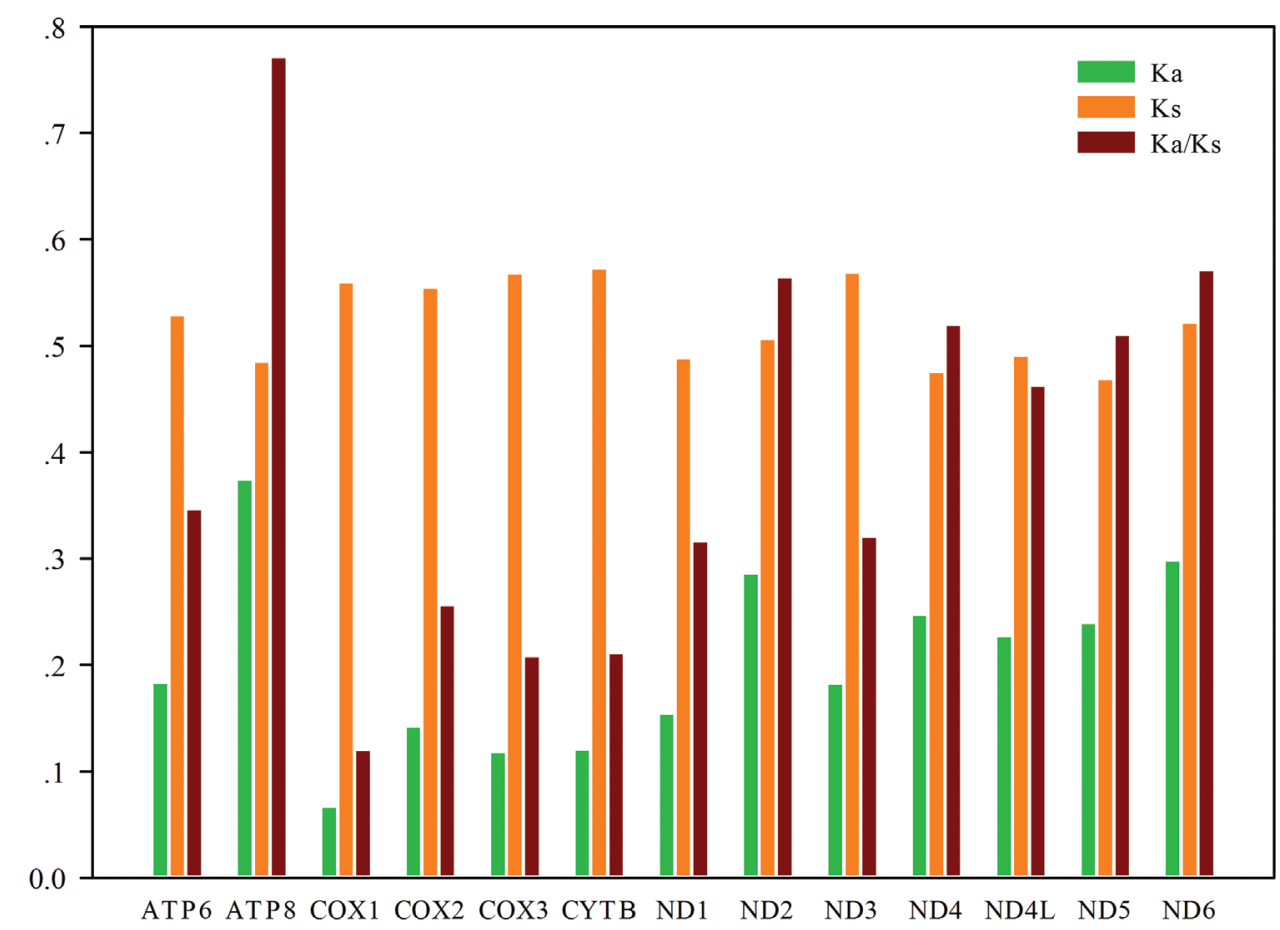

Figure 4. Evolutionary rates of 13 PCGs in Pentatomoidea. Rate of non-synonymous substitutions (Ka), rate of synonymous substitutions (Ks) and ratio of rate of non-synonymous substitutions to rate of synonymous substitutions (Ka/Ks) are calculated for each PCG.

conservative with the slowest rate. The evolutionary rates of the other genes were in the order of ND2 > ND4 > ND5 > ND4L > ATP6 > ND3 > ND1 > COX2 > COX3 > CYTB. Moreover, the Ks values of the 13 PCGs were all greater than the Ka values, and the $\mathrm{Ka} / \mathrm{Ks}$ ratio was $<1$, which indicates that the genes are subject to purifying selection.

\section{tRNA genes, rRNA genes, and the control region}

We detected 22 tRNA genes, which can transport all 20 amino acids, in the mitogenome of $P$. rufipes. There are two tRNAs each for leucine and serine: trnL1 (CUN) and trnL2 (UUR), and trnS1 (AGN) and trnS2 (UCN), respectively. The anticodons of $\operatorname{trnL}$ are TAA and TAG, and the anticodons of trnS are ACT and TGA. The 22 tRNA genes span 1,481 bp, between 62 and $74 \mathrm{bp}$ in length. Although trnS1 lacks a dihydrouridine arm, the other tRNA genes all have the classic clover leaf secondary structure. In addition to the typical base pairs (A-U and G-C), some wobble G-U pairs appear in these secondary structures, which can form stable chemical bonds between $G$ and $\mathrm{U}$; In addition, atypical pairing of U-U and U-C is also found (Fig. 5).

The two P. rufipes rRNA genes (12S rRNA and 16S rRNA) are encoded on the $\mathrm{N}$-strand. The $16 \mathrm{~S}$ rRNA gene is located between $\operatorname{trnL} 1(\mathrm{CUN})$ and $\operatorname{trnV}$, which is 

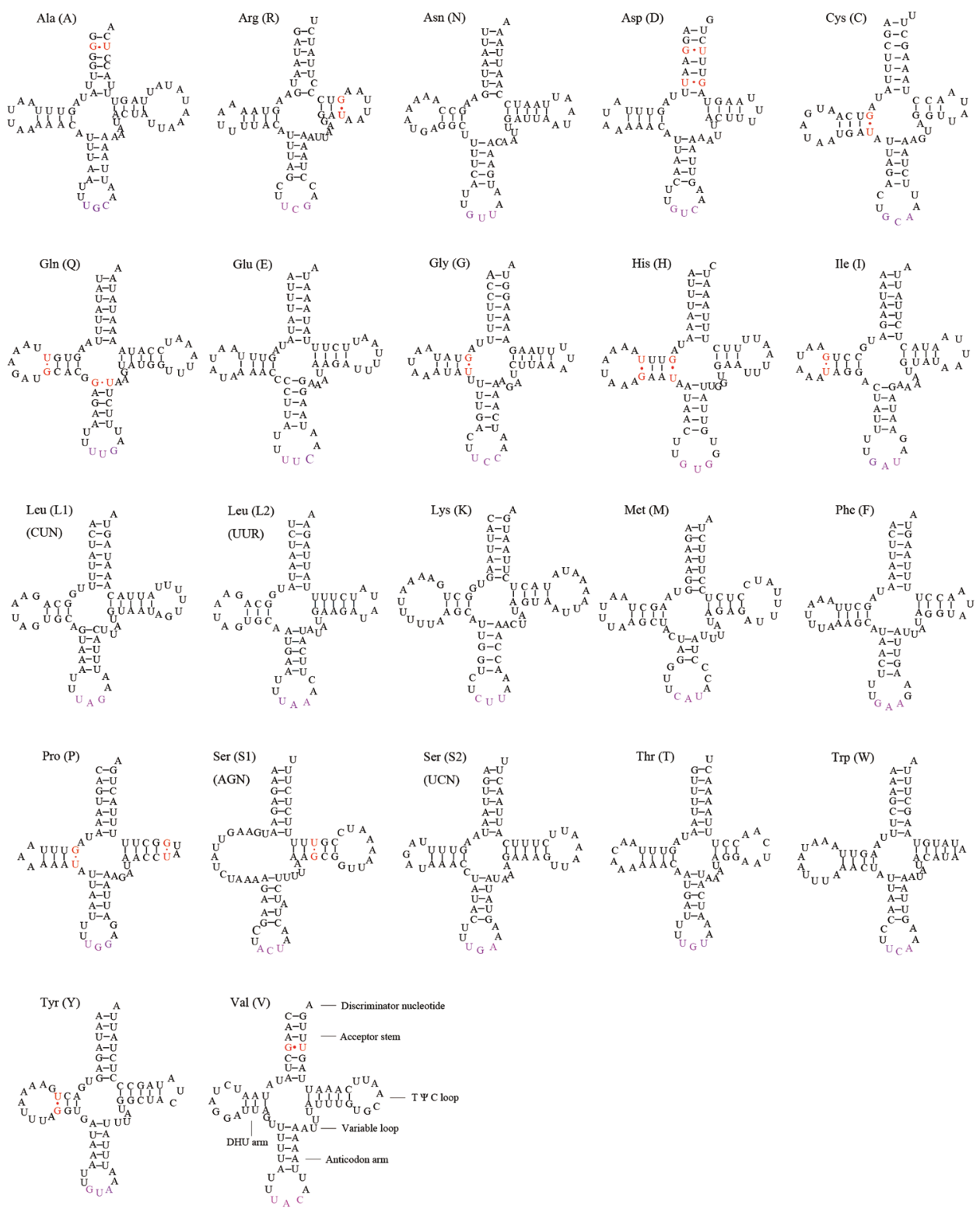

Figure 5. Predicted secondary structure of tRNA genes in the Pentatoma rufipes mitogenome.

1,277 bp in length, and there is no gene overlap between $16 \mathrm{~S}$ rRNA and the two tRNA genes. The $12 \mathrm{~S}$ rRNA gene (821 bp) is located between trnV and the control region, similar to the published pentatomid mitogenomes. The base content of the rRNA genes is in the order of $\mathrm{T}(44.2 \%)>\mathrm{A}(35.6 \%)>\mathrm{G}(12.6 \%)>\mathrm{C}(7.6 \%)$. The ATskews are negative, and the GC-skews are positive. The complete secondary structures of the $12 S$ rRNA and $16 S$ rRNA genes are shown in Figures 6, 7, respectively. 


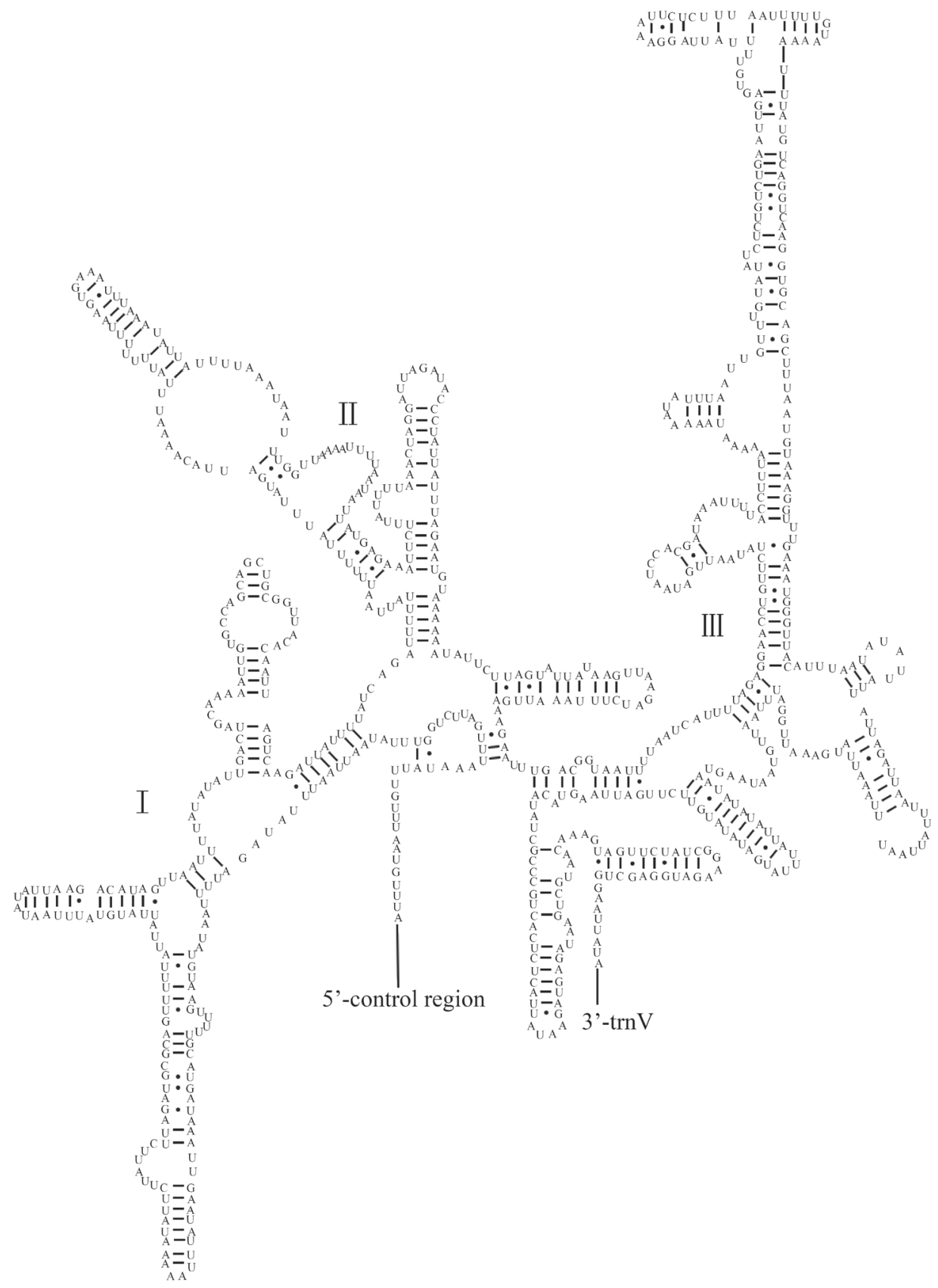

Figure 6. Predicted secondary structure of the $12 \mathrm{~S}$ rRNA in the Pentatoma rufipes mitogenome.

The control region of the mitogenome of P. rufipes is located between the $12 S$ rRNA gene and trnI. The control region is $1,180 \mathrm{bp}$ long, making it the longest noncoding region in the mitogenome, and has an $\mathrm{A}+\mathrm{T}$ content of $78.7 \%$. The AT- 


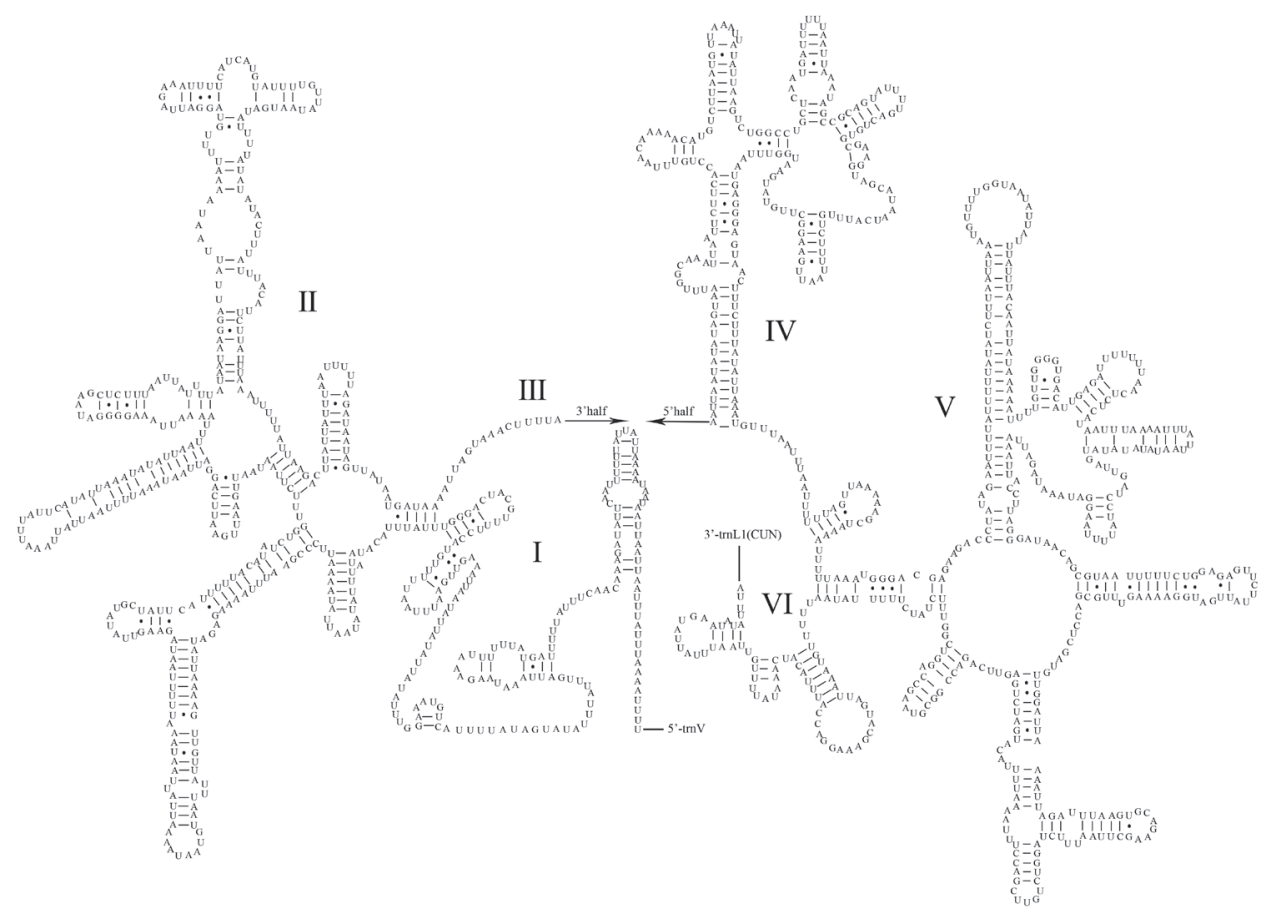

Figure 7. Predicted secondary structure of the $16 \mathrm{~S}$ rRNA in the Pentatoma rufipes mitogenome.

skew and GC-skew in the control area are -0.03 and -0.28 , respectively, indicating that the content of $\mathrm{T}$ is higher than that of $\mathrm{A}$ and the content of $\mathrm{C}$ is higher than that of G.

\section{Saturation test}

To eliminate the negative effect of the substitution saturation in the phylogenetic analysis, saturation tests on the three data sets were conducted. Nucleotide sequence substitution saturation is usually determined by analyzing the relationship between the transition and transversion values against the corresponding corrected genetic distance. In all tests, the Xia saturation index (Iss) was below the critical values for a symmetric (Iss.cSym) and asymmetric (Iss.cAsym) topology (Fig. 8). The values for base transition and transversion were linearly associated with the corrected genetic distance, indicating that the nucleotide sequences of these three datasets were not saturated, making them suitable for constructing phylogenetic trees.

\section{Phylogenetic analyses}

We reconstructed the phylogenetic trees of eight families in Pentatomoidea from three datasets (PCGRNA, PCG, and PCG12) using Bayesian inference method. The 

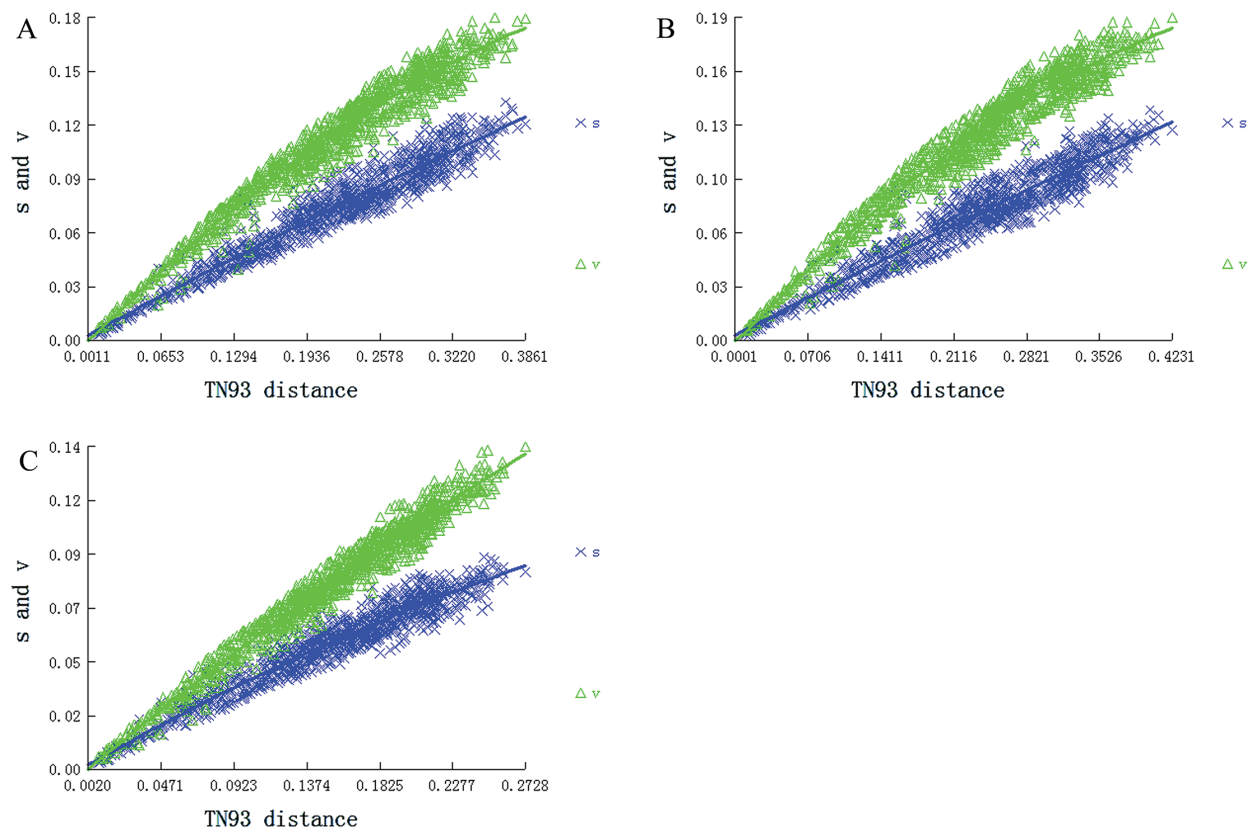

Figure 8. Substitution patterns of PCGRNA, PCG and PCG12 matrices. The graphs represent the increase in TN93 distance A PCGRNA saturation plot B PCG saturation plot C PCG12 saturation plot.

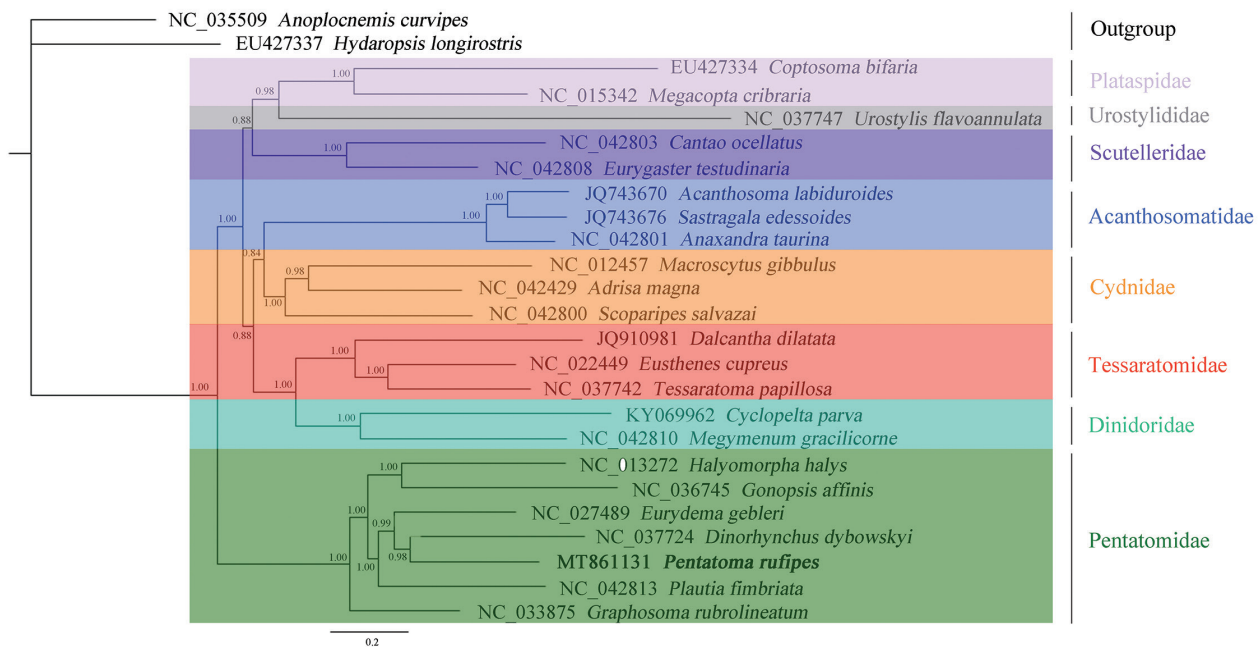

Figure 9. Phylogenetic tree inferred from PCGRNA constructed using BI analysis. The number on the branches indicates Bayesian posterior probabilities.

topological structures of the trees were similar, especially PCG and PCG12 showed similar family-level relationships (Figs 9-11). Among the three trees, the Bayesian posterior probability value of the phylogenetic tree based on the PCGRNA data- 


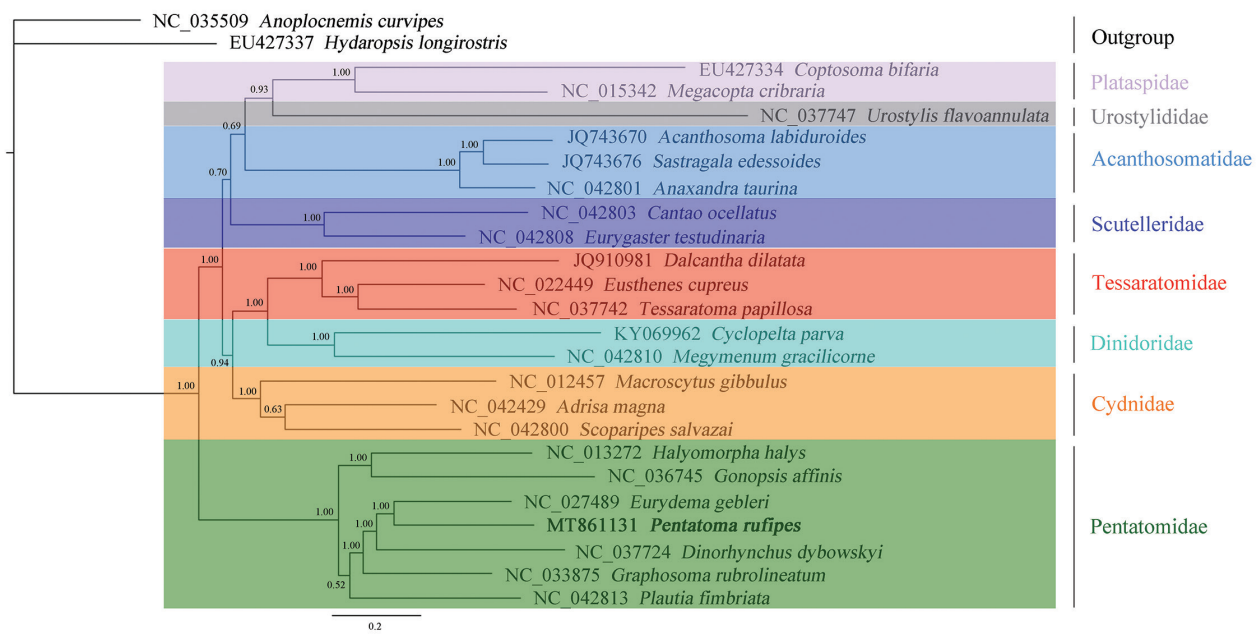

Figure 10. Phylogenetic tree inferred from PCG constructed using BI analysis. The number on the branches indicates Bayesian posterior probabilities.

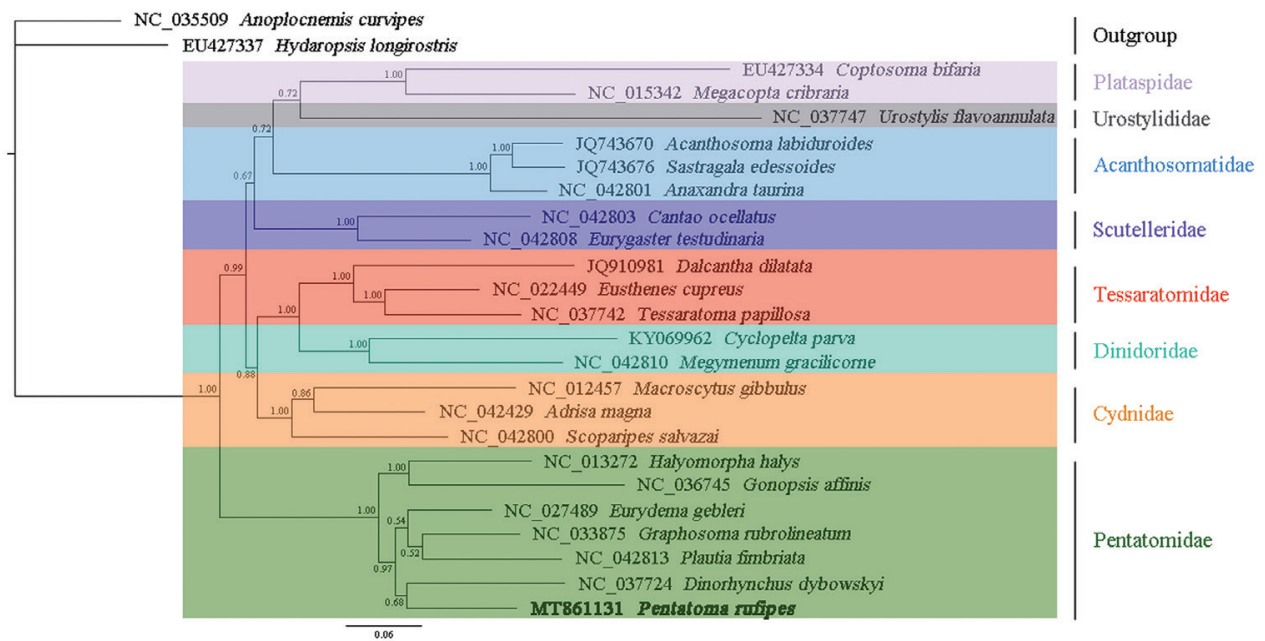

Figure II. Phylogenetic tree inferred from PCG12 constructed using BI analysis. The number on the branches indicates Bayesian posterior probabilities.

set was the highest. Phylogenetic analysis based on PCGRNA data showed that $P$. rufipes and Dinorhynchus dybowskyi Jakovlev were closely related, these two species formed sister groups with E. gebleri, and P. rufipes and Graphosoma rubrolineatum (Westwood) had the farthest relationship. However, the results in the phylogenetic analysis based on PCG data were somewhat different from the above. In this analysis, P. rufipes and E. gebleri were the most closely related species, and they were sister groups with $D$. dybowskyi. 


\section{Discussion and conclusions}

In this study, we sequenced the complete mitogenome of $P$. rufipes using NGS technology, revealing a mitogenome that is 15,887-bp-long containing 37 genes. The order of the 37 genes is consistent with other published mitogenome of Hemiptera (Hua et al. 2009; Zhang et al. 2018; Zhao et al. 2019). There are three obvious overlapping regions in mitochondrial genome of $P$. rufipes. The longest overlap located between $\operatorname{trnW}$ and $\operatorname{trnC}$, which is $8 \mathrm{bp}$ in length, and the overlap bases are AAGCTTTA. This overlap also showed in most species of Pentatomidae (Yuan et al. 2015a and Zhao et al. 2019). The other two pairs of genes, namely ATP8/ATP6 and ND4/ND4L, overlap by $7 \mathrm{bp}$, and both overlap bases are ATGATAA, which is consistent with other hemipteran insects (Zhang et al. 2019; Zhao et al. 2020). The longest spacer region falls between $\operatorname{trnS} 2$ and ND1, which is consistent with the findings of other studies (Hua et al. 2008; Zhao et al. 2019). The difference of mitogenome size between P. rufipes and other species of Hemiptera due to the length difference of the noncoding region.

The composition of the four bases in the P. rufipes mitogenome suggested highly unbalanced $(A>T>C>G)$. The nucleotide composition shows an obvious AT preference, and the entire genome shows AT-skew and CG-skew. The above characteristics of mitogenome base composition of $P$. rufipes are ubiquitous to all sequenced species of Pentatomidae. The preference of bases composition is generally considered to be caused by asymmetric mutation and selection pressure of the four bases (Brown et al. 2005). Consistent with most species of Hemiptera, the PCGs of this species use the common triplet codon ATN as the start codon, TAA and a single T as the stop codon (Hua et al. 2008; Zhao et al. 2019).

The secondary structures of tRNAs for P. rufipes is conserved and trnS1 lacks DHU arm, these features meet the character of metazoan mitochondrial genomes (Wolstenholme 1992). In addition to the typical Watson-Crick pairing (G-C and A-U), there are also some typical pairings such as U-G, U-C and U-U. Some scholars have proposed that those tRNAs with non-Watson-Crick matches can be transformed into fully functional proteins through post-transcriptional mechanisms (Chao et al. 2008; Pons et al. 2014). The rRNA secondary structure of this species is also conserved. The $12 S$ rRNA sequence includes three domains and the $16 \mathrm{~S}$ rRNA sequence includes six domains (domain III is absent), which is similar to pentatomoid insects.

The phylogenetic result suggested that there are some different topology compared to other studies, but we infer that the possible reasons are as follows: first, the number and taxon of samples selected are different. In this study, the phylogenetic relationship between Pentatoma and Plautia was relatively close, and they were far from Graphosoma. However, when the phylogenetic tree was constructed with Pentatoma semiannula$t a$, the relationship between Pentatoma and Graphosoma was closer (Wang et al. 2021). Second, the selection of outgroup also affects the topological structure of phylogenetic tree. Comparing our results with Zhao et al. (2017) and Liu et al. (2019), because of the three studies choose different species as the outgroup, we got different phylogenies. Third, different molecular markers also might affect phylogenetic relationships. Grazia 
et al. (2008) supported the monophyly of Pentatomoidea and most of the included families based on morphological characters and molecular markers (16S rRNA, 18S rRNA, 28S rRNA, and COI). Lis et al. (2012) constructed similar phylogenetic trees to our study using $12 \mathrm{~S}$ and $16 \mathrm{~S}$ rDNA datasets. Tian et al. (2011) (based on Hox genes), Liu et al. (2019) (based on PCGRNA and PCG12RNA) and Li et al. (2005) (based on 18S rDNA and COX1 sequence) also put forward their own opinions on the phylogenetic relationship of the superfamily. Our three topologies revealed that the Bayesian posterior probability of the tree based on PCGRNA sequences was significantly higher than that of the trees based on the PCG data, indicating that inclusion of tRNA and rRNA genes improves the accuracy of the analysis, which is consistent with the findings of the study conducted by Cameron et al. $(2007,2009)$.

In summary, the mitogenome of $P$. rufipes has typical sequence structures, and the gene content, nucleotide composition, codon usage, RNA structures, and rates of PCGs evolution are similar to those of other published pentatomid genomes. The mitochondrial genome of $P$. rufipes reveals the phylogenetic location of Pentatoma, indicating that the mitogenome can be used to reveal phylogenetic relationships among different taxonomic levels of insects. However, more insect mitogenomes should be sequenced, which would provide more insight into the phylogenetic relationships of species from different taxa.

\section{Acknowledgments}

This research was supported by National Science Foundation of China [no. 31872272 and 31501876]; Shanxi Scholarship Council of China [no. 2020-064 and 2020-065], and Shanxi Graduate Innovation Project of Shanxi Province [no. 2020SY215]. The authors have declared that no competing interests exist.

\section{References}

Bai J, Xu S, Nie Z, Wang Y, Zhu C, Wang Y, Min W, Cai Y, Zou J, Zhou X (2018) The complete mitochondrial genome of Huananpotamon lichuanense (Decapoda: Brachyura) with phylogenetic implications for freshwater crabs. Gene 646: 217-226. https://doi. org/10.1016/j.gene.2018.01.015

Ballard JWO, Whitlock MC (2004) The incomplete natural history of mitochondria. Molecular Ecology 13: 729-744. https://doi.org/10.1046/j.1365-294X.2003.02063.x

Bankevich A, Nurk S, Antipov D, Gurevich AA, Dvorkin M, Kulikov AS, Lesin VM, Nikolenko SI, Pham S, Prjibelski AD, Pyshkin AV, Sirotkin AV, Vyahhi N, Tesler G, Alekseyev MA, Pevzner PA (2012) SPAdes: a new genome assembly algorithm and its applications to single-cell sequencing. Journal of Computational Biology 19: 455-477. https://doi. org $/ 10.1089 / \mathrm{cmb} .2012 .0021$

Bantock T, Botting J (2013) British bugs: an online identification guide to UK Hemiptera. http://www.britishbugs.org.uk/index.html 
Bernt M, Donath A, Jühling F, Externbrink F, Florentz C, Fritzsch G, Pütz J, Middendorf M, Stadler PF (2013) MITOS: improved de novo metazoan mitochondrial genome annotation. Molecular Phylogenetics and Evolution 69: 313-319. https://doi.org/10.1016/j.ympev.2012.08.023

Brown TA, Cecconi C, Tkachuk AN, Bustamante C, Clayton DA (2005) Replication of mitochondrial DNA occurs by strand displacement with alternative light-strand origins, not via a strand-coupled mechanism. Genes \& Development 19: 2466-2476. https://doi. org/10.1101/gad.1352105

Boore JL (1999) Animal mitochondrial genomes. Nucleic Acids Research 27: 1767-1780. https://doi.org/10.1093/nar/27.8.1767

Boore JL (2006) The use of genome-level characters for phylogenetic reconstruction. Trends in Ecology and Evolution 21: 439-446. https://doi.org/10.1016/j.tree.2006.05.009

Bu Y, Zheng ZM, Guo K (2005) Sequence analysis of mtDNA-COII gene and molecular phylogeny on five species of Pentatoma (Hemiptera: Pentatomidae). Entomotaxonomia 27: 90-96.

Cameron SL (2014) Insect mitochondrial genomics: implications for evolution and phylogeny. Annual Review of Entomology 59: 95-117. https://doi.org/10.1146/annurev-ento-011613-162007

Cameron SL, Whiting MF (2008) The complete mitochondrial genome of the tobacco hornworm, Manduca sexta, (Insecta: Lepidoptera: Sphingidae), and an examination of mitochondrial gene variability within butterflies and moths. Gene 408: 112-123. https://doi. org/10.1016/j.gene.2007.10.023

Cameron SL, Lambkin CL, Barker SC, Whiting MF (2007) A mitochondrial genome phylogeny of Diptera: whole genome sequence data accurately resolve relationships over broad timescales with high precision. Systematic Entomology 32: 40-59. https://doi. org/10.1111/j.1365-3113.2006.00355.x

Cameron SL, Sullivan J, Song H, Miller KB, Whiting MF (2009) A mitochondrial genome phylogeny of the Neuropterida (lace-wings, alderflies and snakeflies) and their relationship to the other holometabolous insect orders. Zoologica Scripta 38: 575-590. https://doi. org/10.1111/j.1463-6409.2009.00392.x

Chao JA, Patskovsky Y, Almo SC, Singer RH (2008) Structural basis for the coevolution of a viral RNA-protein complex. Nature Structural \& Molecular Biology 15: 103-105. https:// doi.org/10.1038/nsmb1327

Clary DO, Wolstenholme DR (1985) The mitochondrial DNA molecule of Drosophila yakuba: nucleotide sequence, gene organization, and genetic code. Journal of Molecular Evolution 22: 252-271. https://doi.org/10.1007/BF02099755

Coil D, Jospin G, Darling AE (2015) A5-miseq: an updated pipeline to assemble microbial genomes from Illumina MiSeq data. Bioinformatics 31: 587-589. https://doi.org/10.1093/ bioinformatics/btu661

Edgar RC (2004) MUSCLE: a multiple sequence alignment method with reduced time and space complexity. BMC Bioinformatics 5: e113. https://doi.org/10.1186/1471-2105-5-113

Fan ZH, Liu GQ (2012) Bifurcipentatoma, a new genus of pentatomini with descriptions of two new species from China (Hemiptera: Heteroptera: Pentatomidae). Zootaxa 28: 14-28. https://doi.org/10.11646/zootaxa.3274.1.2

Grazia J, Schuh RT, Wheeler WC (2008) Phylogenetic relationships of family groups in Pentatomoidea based on morphology and DNA sequences (Insecta: Heteroptera). Cladistics 24: 932-976. https://doi.org/10.1111/j.1096-0031.2008.00224.x 
Hamilton I, Heath J (1976) Predation of Pentatoma rufipes (L.) Hemiptera : Pentatomidae ) upon Zygaena filipendulae (L .) (Lepidoptera: Zygaenidae). The Irish Naturalists' Journal 18: 337.

Henry TJ (1997) Phylogenetic analysis of family groups within the infraorder Pentatomomorpha (Hemiptera: Heteroptera), with emphasis on the Lygaeoidea. Annals of the Entomological Society of America 90: 275-301. https://doi.org/10.1093/aesa/90.3.275

Hsiao TY (1977) A Handbook for the Determination of the Chinese Heteroptera. Science Press, Beijing, 127-128.

Hua J, Li M, Dong P, Cui Y, Xie Q, Bu W (2008) Comparative and phylogenomic studies on the mitochondrial genomes of Pentatomomorpha (Insecta: Hemiptera: Heteroptera). BMC Genomics 9: 1-15. https://doi.org/10.1186/1471-2164-9-610

Hua J, Li M, Dong P, Cui Y, Xie Q, Bu W (2009) Phylogenetic analysis of the true water bugs (Insecta: Hemiptera: Heteroptera: Nepomorpha): evidence from mitochondrial genomes. BMC Evolutionary Biology 9: 1-11. https://doi.org/10.1186/1471-2148-9-134

Kearse M, Moir R, Wilson A, Stones-Havas S, Cheung M, Sturrock S, Buxton S, Cooper A, Markowitz S, Duran C, Thierer T, Ashton B, Meintjes P, Drummond A (2012) Geneious basic: an integrated and extendable desktop software platform for the organization and analysis of sequence data. Bioinformatics 28: 1647-1649. https://doi.org/10.1093/bioinformatics/bts199

Kumar S, Stecher G, Tamura K, Medicine E (2016) MEGA7: molecular evolutionary genetics analysis version 7.0 for bigger datasets 33: 1-11. https://doi.org/10.1093/molbev/msw054

Lanfear R, Calcott B, Ho SYW, Guindon S (2012) PartitionFinder: combined selection of partitioning schemes and substitution models for phylogenetic analyses. Molecular Biology and Evolution 29: 1695-1701. https://doi.org/10.1093/molbev/mss020

Li HM, Deng RQ, Wang JW, Chen ZY, Jia FL, Wang XZ (2005) A preliminary phylogeny of the Pentatomomorpha (Hemiptera: Heteroptera) based on nuclear 18S rDNA and mitochondrial DNA sequences. Molecular Phylogenetics and Evolution 37: 313-326. https:// doi.org/10.1016/j.ympev.2005.07.013

Liang QY (2009) Molecular phylogeny analysis of 9 Species of Pentatoma (Hemiptera: Pentatomidae) inferred from COI gene sequence. Entomotaxonomia 31: 105-114.

Ling ZP, Zheng LY (1987) A study on the systematics of Pentatoma olivier (Heteroptera: Pentatomidae). Entomotaxonomia 9: 39-50.

Liu YQ, Song F, Jiang P, Wilson JJ, Cai WZ, Li H (2018) Compositional heterogeneity in true bug mitochondrial phylogenomics. Molecular Phylogenetics and Evolution 118: 135-144. https://doi.org/10.1016/j.ympev.2017.09.025

Liu YQ, Li H, Song F, Zhao YS, Wilson JJ, Cai WZ (2019) Higher-level phylogeny and evolutionary history of Pentatomomorpha (Hemiptera: Heteroptera) inferred from mitochondrial genome sequences. Systematic Entomology 44: 810-819. https://doi.org/10.1111/syen.12357

Lis JA, Lis P, Ziaja DJ, Kocorek A (2012) Systematic position of dinidoridae within the superfamily pentatomoidea (Hemiptera: Heteroptera) revealed by the bayesian phylogenetic analysis of the mitochondrial $12 S$ and $16 S$ rDNA sequences. Zootaxa 3423: 61-68. https://doi.org/10.11646/zootaxa.3423.1.5

Lis JA, Ziaja DJ, Lis B, Gradowska P (2017) Non-monophyly of the "cydnoid” complex within Pentatomoidea (Hemiptera: Heteroptera) revealed by Bayesian phylogenetic analysis of nuclear rDNA sequences. Arthropod Systematics \& Phylogeny 75: 481-496. 
Lowe TM, Eddy SR (1997) tRNAscan-SE: a program for improved detection of transfer RNA genes in genomic sequence. Nucleic Acids Research 25: 955-964. https://doi.org/10.1093/ nar/25.5.955

Nass MM, Nass S (1963) Intramitochondrial fibers with DNA characteristics. I. fixation and electron staining reactions. The Journal of Cell biology 19: 593-611. https://doi. org/10.1083/jcb.19.3.593

Neupert S, Russell WK, Russell DH, López JD, Predel R, Nachman RJ (2009) Neuropeptides in Heteroptera: identification of allatotropin-related peptide and tachykinin-related peptides using MALDI-TOF mass spectrometry. Peptides 30: 483-488. https://doi. org/10.1016/j.peptides.2008.11.009

Perna NT, Kocher TD (1995) Patterns of nucleotide composition at fourfold degenerate sites of animal mitochondrial genomes. Journal of Molecular Evolution 41: 353-358. https:// doi.org/10.1007/BF01215182

Peusens G, Beliën T (2012) Life cycle and control of the forest bug Pentatoma rufipes L. in organically managed pear orchards. Communications in Agricultural and Applied Biological Sciences 77: 663-666.

Pons J, Bauzà-Ribot MM, Jaume D, Juan C (2014) Next-generation sequencing, phylogenetic signal and comparative mitogenomic analyses in Metacrangonyctidae (Amphipoda: Crustacea). BioMed Central 15: e566. https://doi.org/10.1186/1471-2164-15-566

Powell G (2020) The biology and control of an emerging shield bug pest , Pentatoma rufipes (L.) (Hemiptera: Pentatomidae). Agricultural and Forest Entomology 22: 298-308. https:// doi.org/10.1111/afe.12408

Rider DA, Schwertner CF, Vilímová J, Rédei, D, Kment P, Thomas DB (2018) Higher systematics of the Pentatomoidea. In: Mcpherson JE (Ed.) Invasive Stink Bugs and Related Species (Pentatomoidea) CRC Press, London, 25-193. https://doi.org/10.1201/9781315371221-2

Ronquist F, Teslenko M, Van Der Mark P, Ayres DL, Darling A, Höhna S, Larget B, Liu L, Suchard MA, Huelsenbeck JP (2012) MrBayes 3.2: efficient Bayesian phylogenetic inference and model choice across a large model space. Systematic Biology 61: 539-542. https://doi.org/10.1093/sysbio/sys029

Schaefer CW (1993) The Pentatomomorpha (Hemiptera: Heteroptera): an annotated outline of its systematics history. European Journal of Entomology 90: 105-122.

Simon S, Hadrys HA (2013) A comparative analysis of complete mitochondrial genomes among Hexapoda. Molecular Phylogenetics and Evolution 69: 393-403. https://doi. org/10.1016/j.ympev.2013.03.033

Tian X, Xie Q, Li M, Gao C, Cui Y, Xi L, Bu W (2011) Phylogeny of pentatomomorphan bugs (Hemiptera-Heteroptera: Pentatomomorpha) based on six Hox gene fragments. Zootaxa 2888: 57-68. https://doi.org/10.11646/zootaxa.2888.1.5

Wang J, Ji YT, Li H, Song F, Zhang LS, Wang MQ (2021) Characterization of the complete mitochondrial genome of Pentatoma semiannulata (Hemiptera: Pentatomidae). Mitochondrial DNA Part B: Resources 6: 750-752. https://doi.org/10.1080/23802359.2021.1875912

Wu YZ, Yu SS, Wang YH, Wu HY, Li XR, Men XY, Zhang YW, Rédei D, Xie Q, Bu WJ (2016) The evolutionary position of lestoniidae revealed by molecular autapomorphies in the secondary structure of rrna besides phylogenetic reconstruction (Insecta: Hemiptera: Heteroptera). Zoological Journal of the Linnean Society 4: 750-763. https://doi.org/10.1111/zoj.12385 
Wu YZ, Rédei D, Eger Jr J, Wang YH, Wu HY, Carapezza A, Kment P, Cai B, Sun XY, Guo PL, Luo JY, Xie Q (2017) Phylogeny and the colourful history of jewel bugs (Insecta: Hemiptera: Scutelleridae). Cladistics 34: 502-516. https://doi.org/10.1111/cla.12224

Xia XH, Xie Z (2001) DAMBE: software package for data analysis in molecular biology and evolution. The Journal of Heredity 92: 371-373. https://doi.org/10.1093/jhered/92.4.371

Xia XH, Lemey P (2009) Assessing substitution saturation with DAMBE. In: Lemey P, Salemi M, Vandamme AM (Eds) The Phylogenetic Handbook: a Practical Approach to Phylogenetic Analysis and Hypothesis Testing. Cambridge University Press, Cambridge, 615-630. https://doi.org/10.1017/CBO9780511819049.022

Yuan M, Guo Z (2016) Research progress of mitochondrial genomes of Hemiptera Insects. Scientia Sinica Vitae 46: 151-166. https://doi.org/10.1360/N052015-00229

Yuan ML, Zhang QL, Guo ZL, Wang J, Shen YY (2015a) Comparative mitogenomic analysis of the superfamily Pentatomoidea (Insecta: Hemiptera: Heteroptera) and phylogenetic implications. BMC Genomics 16: e460. https://doi.org/10.1186/s12864-015-1679-x

Yuan ML, Zhang QL, Guo ZL, Wang J, Shen YY (2015b) The complete mitochondrial genome of Corizus tetraspilus (Hemiptera: Rhopalidae) and phylogenetic analysis of Pentatomomorpha. PLoS ONE 10: e0129003. https://doi.org/10.1371/journal.pone.0129003

Zhang DL, Li M, Li T, Yuan JJ, Bu WJ (2018) A mitochondrial genome of Micronectidae and implications for its phylogenetic position. International Journal of Biological Macromolecules 119: 747-757. https://doi.org/10.1016/j.ijbiomac.2018.07.191

Zhang DL, Gao J, Li M, Yuan J, Liang J, Yang H, Bu W (2019) The complete mitochondrial genome of Tetraphleps aterrimus (Hemiptera: Anthocoridae): Genomic comparisons and phylogenetic analysis of Cimicomorpha. International Journal of Biological Macromolecules 130: 369-377. https://doi.org/10.1016/j.ijbiomac.2019.02.130

Zhao L, Wei J, Lu Y, Wang B, Hao S, Zhao Q (2019) The complete mitochondrial genome of Menida violacea (Hemiptera: Pentatomidae) and its phylogenetic implication. Mitochondrial DNA Part B: Resources 4: 1953-1954. https://doi.org/10.1080/23802359.2019.1617055

Zhao Q, Wang J, Wang MQ, Cai B, Zhang HF, Wei JF (2018) Complete mitochondrial genome of Dinorhynchus dybowskyi (Hemiptera: Pentatomidae: Asopinae) and phylogenetic analysis of Pentatomomorpha species. Journal of Insect Science 18: e44. https://doi. org/10.1093/jisesa/iey031

Zhao Q, Cassis G, Zhao L, He YF, Zhang HF, Wei JF (2020) The complete mitochondrial genome of Zicrona caerulea (Linnaeus) (Hemiptera: Pentatomidae: Asopinae) and its phylogenetic implications. Zootaxa 4747: 547-561. https://doi.org/10.11646/zootaxa.4747.3.8

Zhao WQ, Zhao Q, Li M, Wei JF, Zhang XH, Zhang HF (2017) Characterization of the complete mitochondrial genome and phylogenetic implications for Eurydema maracandica (Hemiptera: Pentatomidae). Mitochondrial DNA Part B: Resources 2: 550-551. https:// doi.org/10.1080/23802359.2017.1365649

Zhao WQ, Zhao Q, Li M, Wei JF, Zhang XH, Zhang HF (2019) Comparative mitogenomic analysis of the Eurydema genus in the context of representative Pentatomidae (Hemiptera: Heteroptera) taxa. Journal of insect science 19: 1-12. https://doi.org/10.1093/jisesa/iez122 